\title{
The Politics of Battlefield Preservation: David B. Henderson and the National Military Parks
}

\author{
TIMOTHY B. SMITH
}

THE BROAD-SHOULDERED, rotund Iowa representative took the floor of the U.S. House of Representatives shortly after noon on an early December day in 1894 . His intent was to push through legislation creating a national park in an isolated region of Tennessee, far south of his Hawkeye home. A winding path over many years had brought David Bremner Henderson, Republican congressman from Iowa's Third District, to this point. The momentous Civil War was the key catalyst. During that conflict Henderson and many of the other men sitting in the House chamber that day had fought in the historic Battle of Shiloh on April 6 and 7, 1862. Now, 32 years later, the reunified nation was preserving its battlefields. Shiloh National Military Park, created by Henderson's bill, was the fourth battle site to be preserved by an act of the federal government. Representative Henderson, soon to be Speaker of the House, would go down in history as one of the more vocal battlefield preservationists of his day. ${ }^{1}$

I am grateful to the State Historical Society of Iowa for a research grant that enabled me to complete this article and to Steve Story and Nadine West at Montauk for their help in researching Henderson's life.

1. 53rd Cong., 3rd sess., Congressional Record 27 (1895), 1:17-20; “A Few Incidents of the Life of Speaker Reed's Successor," David Bremner Henderson Papers, Special Collections, University of Iowa Libraries, Iowa City. Shiloh was the fourth battlefield to receive federal dollars for marking lines of battle. Chickamauga-Chattanooga became a park in 1890. Appropriations followed for Antietam in 1890 and Gettysburg in 1893, although Gettysburg would not become a national military park until 1895, after Shiloh.

THE ANNALS OF IOWA 66 (Summer-Fall 2007). (c) The State Historical Society of Iowa, 2007. 
Historians have not closely examined David B. Henderson's life and career, let alone his role in preserving battlefields. But the man and his work are important to American history as a whole, as well as to the history of the battlefield preservation movement in particular. Henderson was the first Speaker of the House from west of the Mississippi River, exemplifying the shift of power from the older areas of the nation to the newer states. But he also represented the end of an era. Henderson was the last Civil War veteran to serve as Speaker, exemplifying the shift from that generation to one with dissimilar goals and values. Finally, Henderson was a vocal battlefield preservationist who fought to save battlefields, foreshadowing efforts that still continue. But he was only partially interested in saving those battlefields, many of which went without any preservation for decades and some of which, even today, are still without federal preservation dollars. Henderson's work in this area can, in fact, be viewed as a case study of the preservation efforts of the generation of Civil War veterans, illustrating both their successes and, even more, their defeats. A study of his life and career, with an emphasis on his preservation efforts, offers important insights into the turn-of-the-century mindset of Civil War veteran leaders who foresaw their own mortality and wanted to leave behind a legacy of significance. ${ }^{2}$

Henderson was just one, although a very powerful one, of many veterans who lined up in the 1890s in support of preserving their old Civil War battlefields. Several factors came together to produce a window of opportunity to save the old battlefields in that decade. Because of the conflict and animosity between the North and South that lasted into the 1880s, the sections could not agree on many issues before then. By the 1890s, however, the sections had tired of the animosity and sought issues that could heal rather than divide. Moving away from the issues of race that had divided them for so long (and which led to the

2. The only full look at Henderson is Willard L. Hoing, “David B. Henderson: Speaker of the House," Iowa Journal of History 55 (1957), 1-34, which apparently resulted from Hoing's master's thesis of the same title (Iowa State Teachers College, 1956). Henderson's retirement is discussed in Forest Maltzman and Eric Lawrence, "Why Did Speaker Henderson Resign? The Page 799 Mystery Is Solved," Public Affairs Report 41 (2000), 7-8. 
rise of Jim Crow and segregation), the North and South sought common bonds. Both sides could agree to commemorate the bravery, honor, and courage of Civil War soldiers of both sides. The decade of the 1890s was thus a favorable time to preserve battlefields, but the small window of opportunity was closing fast. Congress and state legislatures, dominated by veterans such as Henderson who were dedicated to documenting what had happened on those battlefields, would appropriate money in the 1890s, but as that generation of Civil War veterans passed, the likelihood of future funding would diminish. In addition, the existence of almost pristine fields that had not yet experienced the development that would later come in the second industrial revolution would soon be compromised because of the coming urbanization and industrialization. ${ }^{3}$

Thus, under an overarching umbrella of sectional reconciliation, the 1890s saw five battlefields set aside as parks: Chickamauga-Chattanooga, Antietam, Shiloh, Gettysburg, and Vicksburg. Each battlefield had commissions or boards made up of veterans who established them, built them, and governed them. Thousands of veterans, growing more cognizant of their eventual passing, visited the fields, marking their troop positions, dedicating monuments to their units and states, and reunifying the sections. Henderson, a member of the Army of the Tennessee, was deeply involved in the two that memorialized that army (Shiloh and Vicksburg). ${ }^{4}$

Yet Henderson was not involved in every battlefield that was created, or in many more that never saw federal dollars. He was actively engaged in the parks that commemorated his own army's actions, but there is no evidence, beyond voting for the specific bills in Congress, that Henderson was heavily involved in establishing the other western battlefield at Chickamauga or the eastern battlefields at Gettysburg or Antietam. Thus, Henderson seemed to be somewhat ambivalent toward an overall battlefield preservation effort, illustrating that the entire preser-

3. David W. Blight, Race and Reunion: The Civil War in American Memory (Cambridge, MA, 2001); Timothy B. Smith, The Golden Age of Battlefield Preservation: The Decade of the 1890s and the Establishment of America's First Five Military Parks (Knoxville, TN, 2008).

4. Smith, Golden Age of Battlefield Preservation. 
vation phenomenon was fractured and grass-roots-based, with battlefield-specific veterans and congressmen providing the bulk of the support for each different site. Similarly, in the larger context of fiscal conservatism brought on by the Panic of 1893, Henderson as Speaker did not push for additional parks or support an overall effort governing the entire mass of battlefields. Thus, Henderson's park-specific attitude is a good case study of the larger veteran mindset in the 1890s.

Perhaps because of the fractured and incoherent nature of the preservation effort, scholars have not become heavily involved in studying the effort until recently. Most research has been left to the National Park Service, which continues to facilitate the splintering effect by emphasizing park-specific studies. Even among academics, the priority still seems to be park-based studies. Still, a growing body of research is beginning to appear. Concerning Henderson himself, however, precious little information has been published concerning his role in preservation. ${ }^{5}$

5. Henderson is not even mentioned in such seminal works as David Blight, Race and Reunion. On the other hand, the only major study of Henderson's career, Willard L. Hoing, "David B. Henderson," does not mention his preservation efforts. Tantalizing snippets of Henderson's involvement, but with little detail, are in Ronald F. Lee, The Origin and Evolution of the National Military Park Idea (Washington, DC, 1973); Mary Munsell Abroe “'All the Profound Scenes': Federal Preservation of Civil War Battlefields, 1861-1990" (Ph.D. diss., Loyola University, 1996); and Christopher Waldrep, Vicksburg's Long Shadow: The Civil War Legacy of Race and Remembrance (New York, 2005). Timothy B. Smith, This Great Battlefield of Shiloh: History, Memory, and the Establishment of a Civil War National Military Park (Knoxville, TN, 2004), and idem, The Untold Story of Shiloh: The Battle and the Battlefield (Knoxville, TN, 2006), mention Henderson's role at Shiloh; his Golden Age of Battlefield Preservation provides more detail. Still, there is no serious, comprehensive study of Henderson's specific role in battlefield preservation. Other works on battlefield preservation include Edward T. Linenthal, Sacred Ground: Americans and Their Battlefields (Urbana, IL, 1991); Michael W. Panhorst, "Lest We Forget: Monuments and Memorial Sculpture in National Military Parks on Civil War Battlefields, 1861-1917" (Ph.D. diss, University of Delaware, 1988); Richard W. Sellars, Pilgrim Places: Civil War Battlefields, Historic Preservation, and America's First National Military Parks, 1863-1900 (Fort Washington, PA, 2005); Herman Hattaway and A. J. Meek, Gettysburg to Vicksburg: The Five Original Civil War Battlefield Parks (Columbia, MO, 2001); Timothy B. Smith, "David Wilson Reed: The Father of Shiloh National Military Park," Annals of Iowa 62 (2003), 333-59; Terrence J. Winschel, "Stephen D. Lee and the Making of an American Shrine," Journal of Mississippi History 63 (2001), 17-32; Susan T. Trail, "Remembering Antietam: Commemoration and Preservation of a Civil War Battlefield" (Ph.D. diss, University of Maryland, 2005); and Jim Weeks, Gettysburg: Memory, Market, and an American Shrine (Princeton, NJ, 2003). 
DAVID B. HENDERSON was born on March 14, 1840, in Old Deer, Scotland. Having been swindled out of everything he owned, David's father, Thomas Henderson, left Scotland to make a new life in America. Six-year-old David traveled to the United States with his parents on the steamer Brooksly, settling first in Winnebago County, Illinois, and then three years later moving on farther west to Iowa. There, the Henderson family located on a beautiful tract of land in northeastern Iowa. A large sector of land near Postville became known as Henderson Prairie, a name that remains today as descendants of the family still inhabit the area. ${ }^{6}$

The elder Henderson and his boys worked the rich land on Henderson Prairie, making a good living and rising in status in the area. When not in the fields, young David attended the neighborhood school, gaining notoriety as a school wrestler, and at age 18 he continued his education at nearby Upper Iowa University, a newly founded college in Fayette. ${ }^{7}$

In 1861 Henderson was caught up in the whirlwind of war. As the nation split apart, Henderson felt the need to do something to aid his new nation. As he later explained it,

Three brothers of us met one night in 1861 under the old family roof and agreed that in this land of our adoption the hour had come for us to lay our lives at the feet of our common country. We slept none that night. In the morning before the parting, the old father, born in Scotland, too, took down the old family Bible brought from Scotland and, after reading it, kneeling among the little group of Scottish-American children, prayed to the God of Battles to guard us and make us brave for the right. Those three brothers 'all nursed at the same breast' and 'with no barriers between their hearts' went side by side to the war, however, fighting on the same side - the side of their country. ${ }^{8}$

6. Handwritten biography of David B. Henderson, undated, in Henderson Papers, University of Iowa; "A Few Incidents of the Life of Speaker Reed's Successor"; Benjamin F. Shambaugh, Biographies and Portraits of the Progressive Men of Iowa, 2 vols. (Des Moines, 1899), 2:83.

7. George D. Perkins, David Bremner Henderson (n.p., 1906), 3; Shambaugh, Biographies and Portraits, 2:83.

8. Truman S. Stevens, "Miller and Henderson," The Iowa Magazine Section of the Hardin County Ledger 18 (10/18/1923), 682. 
Henderson's service in the Union army would begin a career dedicated to serving the United States of America and the people of Iowa.

The young Henderson was instrumental in organizing a company of students at Upper Iowa University. Feeling ashamed that he had not already joined the cause after President Abraham Lincoln had called for 75,000 troops to put down the rebellion in the South, he asked the faculty for time to speak one night after prayers and laid out plans for the organization of the company. A fellow student remembered Henderson "springing the muster roll on his fellow students in the chapel one evening after prayers; [making] a rousing speech for the old flag and the Union." His call to his fellow students to "drop our books to fight our country's battles" must have been one of the most inspiring speeches of his career. Henderson then enrolled as a private, although the young men wanted him to be their captain. Thinking himself too young and inexperienced for that rank, he proposed his friend William W. Warner, whom the members of the company elected. They then elected Henderson as their first lieutenant. Enough students enrolled for the company to be mustered into federal service as Company C, 12th Iowa Infantry. Henderson called them "a sterling band of brothers"; they called themselves the "University Recruits." 9

The war was not all grandeur and glory for Henderson. In the regiment's first action at Fort Donelson in February 1862, Lieutenant Henderson led the company in a charge on the enemy breastworks and received a frightening but non-lethal "ball through his neck," which forced him to leave the army for nearly two months. Consequently, he was not with his regiment on the morning of April 6, 1862, when it took its position in the Hornet's Nest and ultimately surrendered. David's brother Thomas was there, however, and was killed in the fighting as David was traveling back to his command. David arrived in time to gather

9. Handwritten biography of David B. Henderson and "A Few Incidents of the Life of Speaker Reed's Successor"; Shambaugh, Biographies and Portraits, 83; Perkins, David Bremner Henderson, 3; "Henderson as a Soldier," David B. Henderson Collection, State Historical Society of Iowa (hereafter cited as SHSI), Des Moines; "From the 12th Regiment," undated newspaper clipping, W. W. Warner Collection, SHSI, Des Moines. 


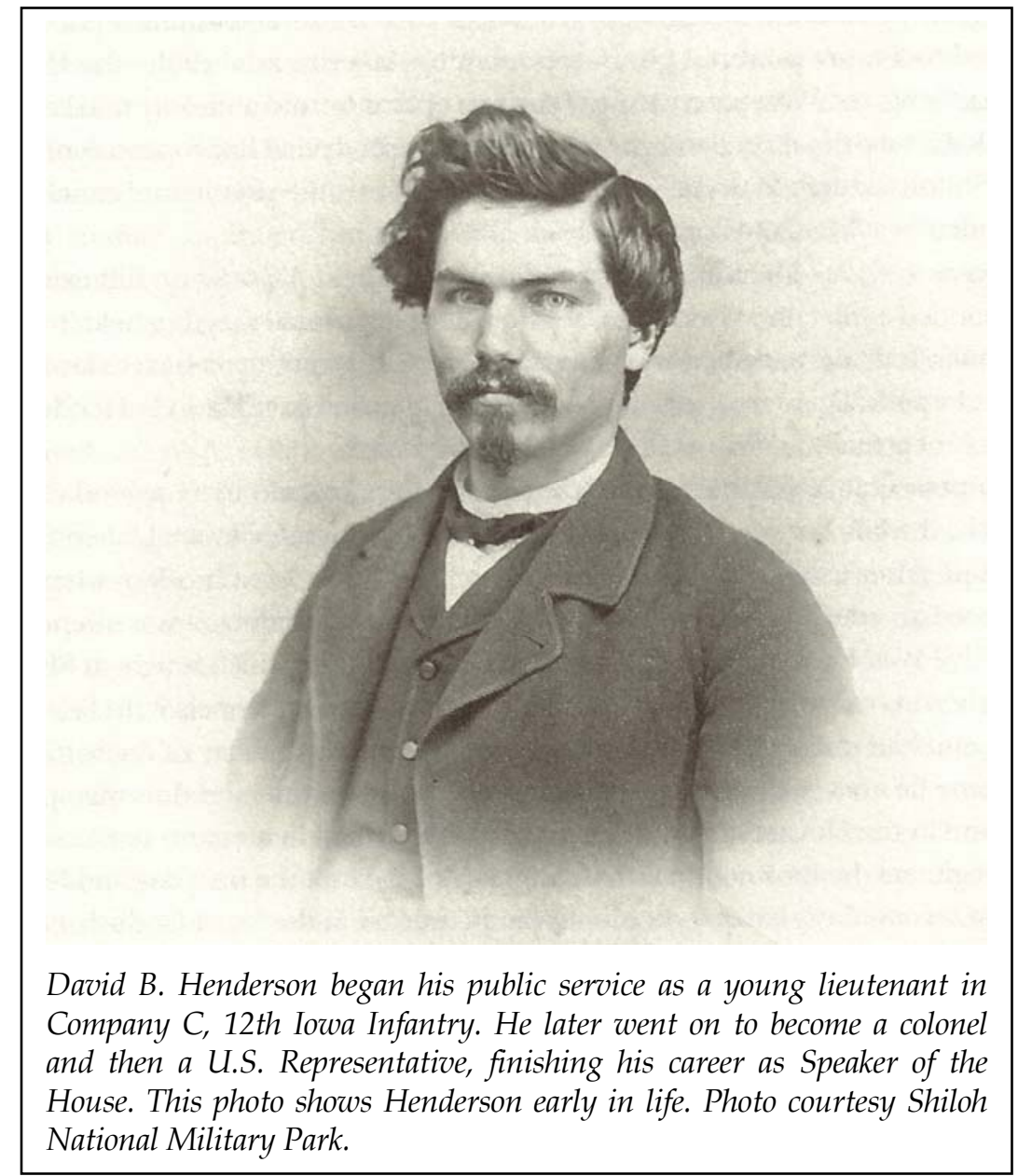

several remnants of the regiment that had avoided capture and led them in battle on the second day. Later, he became acting adjutant of the "Union Brigade," made up of remnants of the regiments that had surrendered at Shiloh in April 1862, and participated in the Siege of Corinth. Henderson endured a harsh illness "while bossing the construction of breastworks," he remembered. He returned to duty in time to fight at the Battle of Corinth, where on October 4 his left foot was "terribly shattered." "It is the worst used up Minnie I ever saw," he casually reported to a friend. Surgeons tried in vain to save 
Henderson's foot, but they eventually had to amputate it, causing him severe pain for several months. 10

He then entered one of the most dismal times of his life. A one-footed infantryman is of little use to an army, so Henderson was discharged from the 12th Iowa. The idea of going home and leaving his comrades was almost unbearable to the young lieutenant. Upon his departure, he wrote them an emotional farewell. "I have encountered disappointments before, [but] this is my greatest," he said. His men responded with reciprocal affection, telling him in a collective letter, "Our hearts are all very, very sad over your great loss, and filled with the deepest regrets when we are conscious that we must lose you from our band." Henderson had repeated trouble with his amputated foot, once even falling while leaning to kiss a girl. "Of course I made a misstep and fell hitting my stump on the floor and laying the bone open again," he wrote to a friend. But Henderson was not about to give up. He had an artificial leg made, which he called "my new foot." 11

Despite his suffering, Henderson's war wound became a badge of honor. It was always evident, reminding his friends and constituents of his honorable war service. Yet Henderson did not seek recognition or sympathy for his wound as some other veterans did. Soon after his wounding, Henderson joked that "I am doomed to go with an emphatic 'Left! Left!' the rest of my life." As time passed, however, he became more guarded about his injury, most likely because of the continuing pain and surgeries he endured. He used a "timber leg" that was covered by his pants and shoe, and he walked with a cane. One colleague wrote toward the end of Henderson's life that "Henderson never speaks of himself or his disability," but he endured

10. "From the 12th Regiment"; Unknown to E. M. Stanton, undated, W. W. Warner Collection; Henderson to "George," 6/13/1862, David B. Henderson Papers, Dubuque County Historical Society, Dubuque (hereafter cited as DCHS); John Durno to brother, 10/25/1862, ibid.; Henderson to "George," 11/17/1862, ibid. For more on Henderson's war career, see his Compiled Service Record in the National Archives.

11. "From the 12th Regiment"; Henderson to William Larrabee, 5/26/1863, William Larrabee Collection Archives, Montauk, Clermont, Iowa; Perkins, David Bremner Henderson, 3; Henderson to "George," 3/21/1863, Henderson Papers, DCHS. 
many surgeries to remove more and more of his leg. The incised portion never healed adequately, possibly due to a mild case of diabetes. 12

Amid the dramatic personal change, Henderson drew on political and social friendships, particularly with Congressman (later senator) William B. Allison, to wrangle an appointment in 1863 as a commissioner on the board of enrollment for Iowa's Third District (northeast Iowa). That position marked the beginning of service to his district that would continue for some four decades. In that position, he managed to enroll many new recruits for the war effort. His work paid off in a way he did not entirely expect. When enough companies had formed to create the new 46th Iowa Infantry, Representative Allison secured the appointment of the 24-year-old Henderson as its colonel. Because colonels rode horses, Henderson was able to serve even with his amputated foot. ${ }^{13}$

On June 10, 1864, Henderson mustered in his 100-days regiment. He drilled them and soon was receiving praise from inspectors. "I can safely say," Henderson wrote with pride, "that it cannot be surpassed by any of the 100 days regts. And I do not think equaled." The regiment served its tour of duty near Memphis, Tennessee, mostly on guard duty along the Memphis and Charleston Railroad. ${ }^{14}$

AFTER THE WAR, in November 1865, Henderson took up law and became a member of the Iowa bar, studying under the state's attorney general and getting what he called his "sheepskin." He served as the Third District's Internal Revenue Service collector until 1869, when he joined the law firm that became Shiras, Van Duzee, and Henderson in Dubuque. He also

12. Henderson to "George," 11/17/1862, Henderson Papers, DCHS; “A Few Incidents of the Life of Speaker Reed's Successor"; D. W. Reed to Cornelius Cadle, 9/28/1897 and 10/1/1897, both in folder 624, box 38, series 1, Shiloh National Military Park (hereafter cited as SNMP).

13. "Historical Sketch: Forty-sixth Regiment Iowa Volunteer Infantry," Roster and Record of Iowa Soldiers in the War of the Rebellion, 6 vols. (Des Moines, 1911), 5:1373-75.

14. Henderson to “George," 7/7/1864, Henderson Papers, DCHS; Shambaugh, Biographies and Portraits, 84 . 
served as assistant district attorney for the Northern District of Iowa until 1871, when he reentered private practice full time. ${ }^{15}$

During the late 1860s and 1870s, Henderson also became involved in politics. He attended several Republican National Conventions, chairing the Iowa delegation for the first time in 1880 . Two years later, citizens of the Third District elected the Republican Henderson as their representative to the U.S. Congress. ${ }^{16}$

Henderson quickly became known as a very personable representative. He gave an intimate and witty stump speech, and occasionally called on the audience to sing the "Star Spangled Banner" or "Marching through Georgia." Even on the floor of the House, his quick wit often entertained his colleagues. In a speech dealing with oleomargarine, he quipped, "I will say to the gentlemen who criticize my pronunciation that it is natural to give the soft sound in speaking of so soft an article." Laughter filled the chamber. ${ }^{17}$

During his terms in office, Henderson steadily gained in status and seniority in the House of Representatives. By the 1890s, he was chairing the Judiciary and Rules committees and playing a key role in many of the big issues of the day. Henderson was anti-imperialist, supported a high protective tariff, and sought a solid gold standard-stances on the big issues that put him at odds with many fellow representatives from his party. Most important, he became Speaker of the House Thomas B. Reed's right-hand man. ${ }^{18}$

Henderson always supported the veterans of his generation, speaking out vehemently in 1894 against cutting Civil War pensions. He was an active member of the Society of the Army of the Tennessee: he often addressed the organization and attended reunions of his regiment, the 12th Iowa. He also kept in touch

15. Perkins, David Bremner Henderson, 4; Shambaugh, Biographies and Portraits, 84; "Henderson as a Soldier," Henderson Collection, SHSI; Henderson to "George," 8/20/1865, Henderson Papers, DCHS.

16. "Henderson as a Soldier," Henderson Collection, SHSI; Perkins, David Bremner Henderson, 4.

17. "A Few Incidents of the Life of Speaker Reed's Successor"; Shambaugh, Biographies and Portraits, 85; "Oleomargarine," May 25-26, 1886, Henderson Papers, DCHS; Henderson to "George," 8/20/1865, ibid.; "Mackenzie Tells of D. B. Henderson," undated newspaper clipping, ibid.

18. Charles A. Boutelle, “The New Speaker," Henderson Papers, DCHS. 
with his old army buddies and took every opportunity to advance their well-being. Many politicians had helped his career along over the years, and Henderson was determined to do the same for his old comrades. ${ }^{19}$

One of the veterans' issues that was near and dear to Henderson's heart was Civil War battlefield preservation. He had been only somewhat involved in the establishment and dedication of America's first national military park at Chickamauga and Chattanooga. His most significant effort, though, involved the later-established park at Shiloh. He did not initiate the idea of establishing a park there, however. In April 1893 Union veterans returned to the battlefield to view the scene of their earlier conflict. Hearing about farmers unearthing skeletons, the veterans determined to ensure that such horrors would cease. Returning to the North on the steamer W. P. Nesbit, the aging soldiers mulled over the idea of establishing a national park like the one already in place at Chickamauga. By the end of the trip, the veterans had formed the Shiloh Battlefield Association. ${ }^{20}$

The association soon began to gather the support of the major veterans' organizations, North and South, such as the Grand Army of the Republic and the Society of the Army of the Tennessee, and, more important, the powerful congressmen who were members of those groups. The Congressional Committee of the Society of the Army of the Tennessee lobbied Congress for the park in 1894 and impressed many members, gaining a "promise of assistance." In the House, former Confederate general Joseph Wheeler of Alabama lent his support while Senator John Sherman of Ohio, brother of Shiloh general William T.

19. "Remarks of Hon. D. B. Henderson of Iowa in the House of Representatives," 8/15/1894, Henderson Papers, University of Iowa; "1st Reunion of the 12th Iowa Infantry," in 12th Iowa Veteran Volunteer Infantry, folder 218, box 4, series 3, SNMP; Report of the Proceedings of the Society of the Army of the Tennessee at the Thirty-third Meeting held at Indianapolis, Indiana, November 13-14, 1901 (Cincinnati, 1902), 33:159-61.

20. Henderson to Henry V. Boynton, 4/30/1890, in "Laudatory Articles" (Letters), Henry Van Ness Boynton Papers, Massachusetts Historical Society, Boston; Report of the Proceedings of the Society of the Army of the Tennessee at the Twentyfifth Meeting held at Chicago, Ills. September 12th and 13th, 1893 (Cincinnati, 1893), 25:59-61; H. V. Boynton, Dedication of the Chickamauga and Chattanooga National Military Park (Washington, DC, 1896), 10, 196. 
Sherman, and Senator Isham G. Harris, former Confederate governor of Tennessee, led the effort in the Senate. ${ }^{21}$

The major congressional backer of the idea was David B. Henderson. Both his service in the war and his ranking authority in Congress made him the obvious veteran to advance the idea of a park at Shiloh. Personal interests also played a role; Henderson's brother Thomas, killed at Shiloh, lay buried in the National Cemetery at Pittsburg Landing, which had been established in 1866. Henderson soon won the job of writing a bill to establish the park.22

Although Congress had begun preserving battlefields at Chickamauga, Antietam, and Gettysburg, no formalized governmental process was in place to oversee them. Consequently, each battlefield had its own sponsor, producing a disjointed yet semicoherent effort that eventually served as the precursor to a national park system. Henderson openly asked for assistance from those who understood more about the subject of national military park legislation than he did. He called on Henry V. Boynton, the Civil War veteran, author, and journalist who had been instrumental in establishing the park at Chickamauga and was then serving as that park's historian. Henderson and Boynton, and no doubt others, soon produced a bill to establish Shiloh National Military Park along the same lines as the earlier Chickamauga legislation. ${ }^{23}$

On March 30, 1894, Henderson introduced his bill, H.R. 6499, in the House of Representatives. The bill was referred to the Committee on Military Affairs, which considered it in June and ultimately approved it unanimously. On June 22, 1894, Representative Joseph H. Outhwaite (D-OH), who chaired the committee, submitted his report recommending that the isolated and "unsightly tract of land" along the Tennessee River be made a national military park. The committee supported preserving Shiloh, which had changed very little since the battle

21. Report of the Proceedings of the Society of the Army of the Tennessee at the Twenty-Sixth Meeting held at Council Bluffs, Iowa, October 3rd and 4th, 1894 (Cincinnati, 1895), 26:126; Memphis Commercial Appeal, 12/5/1894; Proceedings of the Society of the Army of the Tennessee, 1893, 25:59.

22. Proceedings of the Society of the Army of the Tennessee, 1893, 25:59.

23. Proceedings of the Society of the Army of the Tennessee, 1894, 26:127. 
and was owned by local farmers, as a "monument" to the veterans before they "left this world." The committee called on Congress to establish national military parks on other prominent battlefields as well. ${ }^{24}$

Henderson shepherded the bill through the House. He anticipated trouble ahead because 1894 was an election year, and he only had two or three months to get it passed before Congress adjourned. "Appropriations are unpopular before Congressional elections," Henderson admitted. He championed the bill as best he could in late summer, yet remained wary because of Congress's desire to cut spending in the wake of the Panic of 1893. Finally, he worked out a deal. He agreed to delay the bill until the next session, which began after the elections. At that time, according to the agreement, it would be passed. Henderson secured the verbal support of several key congressmen, including Appropriations Committee chair Joseph D. Sayers (D-TX), who promised that he would give "generous cooperation" to H.R. 6499 in the coming session. Confident of victory, Henderson agreed to the delay but continued to call on veterans' organizations to encourage their congressmen to support the legislation. ${ }^{25}$

When Henderson returned to Washington after winning reelection in 1894, he immediately acted to get H.R. 6499 to the floor. On December 4, 1894, the day after Congress assembled, he brought the legislation forward. The House resolved itself into the committee of the whole and set a limit of one hour for debate. Committee on Military Affairs chair Outhwaite acted as the bill's floor manager. After calling the legislation to the House's attention, he yielded to Henderson. ${ }^{26}$

The Iowa representative spoke briefly on "this great battlefield of Shiloh." When he opened the floor for questioning, however, the debate turned negative. Several representatives, out of fiscal concern, criticized the bill as a waste. Most opposition was aimed not so much at the idea of the park itself, but at the entire national military park movement. Some congressmen

24. 53rd Cong., 3rd sess., Congressional Record 27 (1895), 1:19; 53rd Cong., 2nd sess., Congressional Record 26 (1894), 4:3368, 7:6722; 53rd Cong., 2nd sess., House Reports, Report No. 1139, 1-5.

25. Proceedings of the Society of the Army of the Tennessee, 1894, 26:127-28.

26. 53rd Cong., 3rd sess., Congressional Record 27 (1895), 1:20. 
believed that too much money was being spent on a system of military parks that was not coherently administered. Representative Alexander M. Dockery (D-MO) asked that the Shiloh authorization be cut in half to $\$ 75,000$, a figure lower than other parks received. The questions soon became more pointed. Representatives wanted to know how much background work had been done, how much monuments and markers would cost, and how much the park would cost in total. A rattled Henderson, surprised by the ferocity and level of opposition, seemed unable to provide solid answers, but, with Outhwaite's intervention, the House passed the bill nonetheless. ${ }^{27}$

On December 6 the bill moved to the Senate. Tennessee's two Democratic senators, both Shiloh veterans with an interest in seeing a military park established in their state, championed the bill in that body. William Bate chaired the Committee on Military Affairs, which reported the bill favorably, and Bate successfully guided the bill through the legislative process, despite minor opposition from fiscal conservatives. President Grover Cleveland signed the bill into law on December 27, 1894, and Shiloh National Military Park became a reality. ${ }^{28}$

Henderson remained involved in Shiloh's establishment. He successfully petitioned Secretary of War Daniel S. Lamont to appoint his friend and fellow 12th Iowa veteran, David W. Reed, as historian and to name fellow Iowan Cornelius Cadle to chair the commission provided for in the legislation. Henderson continued to assert his influence over subsequent appointments, such as Range Rider (law officer) Francis A. Large, another 12th Iowa veteran. And he was heavily involved in defeating an attempt by members of the Shiloh Battlefield Association to take over the process of park establishment by holding land options as ransom for a position on the commission. Of Eliel T. Lee, secretary of the association, Henderson wrote, "I will not have my kid gloves on if I ever have occasion to speak of him." 29

\section{Ibid., 20-21.}

28. 53rd Cong., 3rd sess., Congressional Record 27 (1895), 1:73, 270, 393, 430, 651; 53rd Cong., 3rd sess., Senate Reports, Report No. 722, 1-4.

29. George B. Davis to Henderson, 2/20/1895, E 713, RG 92, National Archives; Henderson to Cornelius Cadle, 3/29/1895, folder 531, box 35, series 1, SNMP; Henderson to Cadle, 7/7/1895, folder 153, box 13, series 1, SNMP; Henderson 


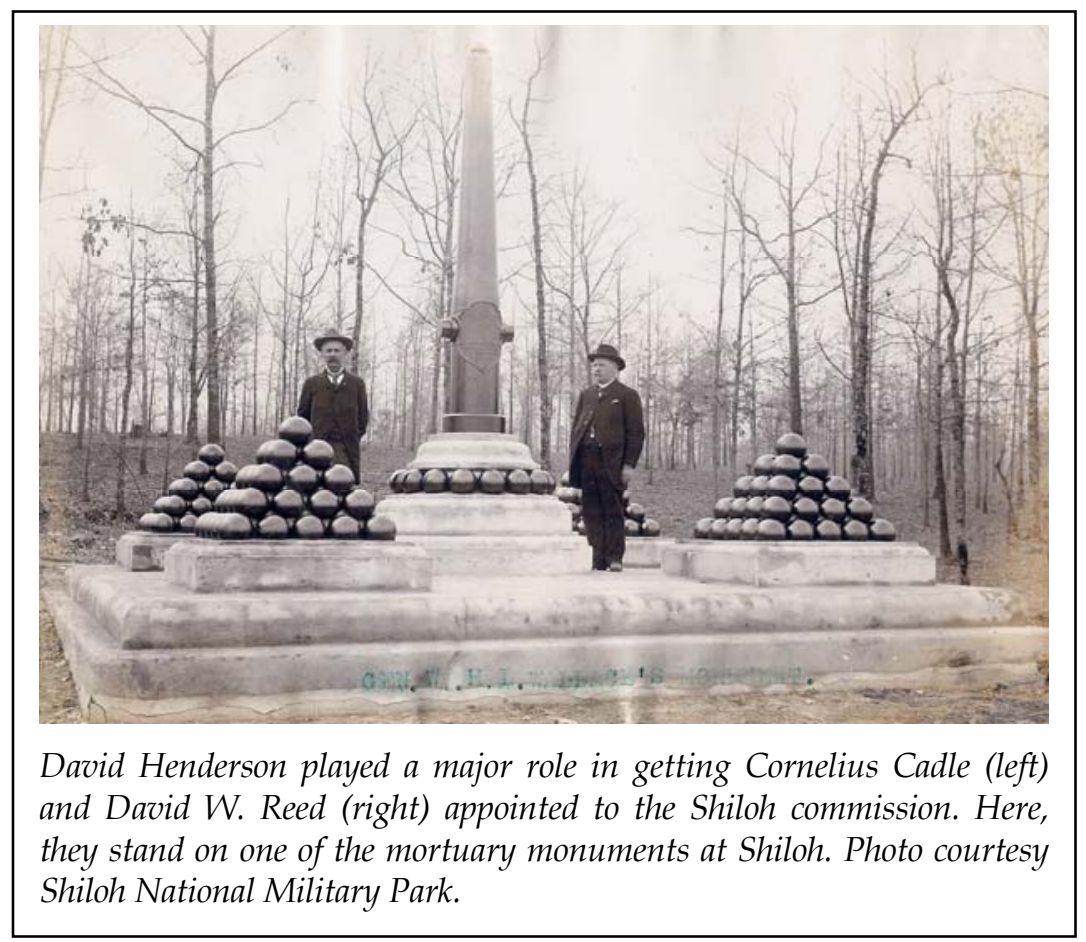

THE CONTROVERSY over the Shiloh bill made Henderson wary of getting any more battlefields preserved. The antagonism that erupted over the cost of national military parks surprised him. Even some veterans were among the congressmen who opposed creating the parks. Confederate veteran Senator Francis M. Cockrell (D-MO) argued, "I think it is an entering wedge to an immense mass of business which will entail upon the country an annual expenditure of thousands and hundreds of thousands of dollars. This is only the entering wedge for making every battlefield a national park." With Chickamauga, Antietam, Gettysburg, and now Shiloh receiving federal dollars, such opposition did not bode well for future battlefield parks. ${ }^{30}$

to D. W. Reed, 1/13/1895, folder 555, box 35, series 1, SNMP; Henderson to Reed, 3/28/1895, folder 91, box 1, series 3, SNMP; Henderson to Cadle, 5/28/ 1896, folder 593, box 36, series 1, SNMP; Henderson to Cadle, 9/30/1897, folder 531, box 35, series 1, SNMP.

30. 53rd Cong., 3rd sess., Congressional Record 27 (1895), 1:430. 
As a result, Henderson was not optimistic when the idea of creating a park at Vicksburg was proposed in 1895. Veteran John F. Merry, an agent for the Illinois Central Railroad and a former captain in the 21st Iowa, led a group that established the Vicksburg National Military Park Association, with former Confederate Lieutenant General Stephen D. Lee, president of the Mississippi Agricultural and Mechanical School in Starkville (today's Mississippi State University), as its president. Henderson told Merry on one of his visits to Washington, "This simply can't be done. . . . The boys have declared they didn't intend spending another dollar on military park appropriations." 31

The association nevertheless began its work in earnest. It incorporated in the state of Mississippi and gathered options for much of the land in question. The officers, especially association secretary William T. Rigby, began writing a bill, which the association delivered to Representative Thomas C. Catchings, Vicksburg's representative in the House, in early 1896. Catchings submitted the legislation, H.R. 4339, on January 20, 1896, and it was referred to the Committee on Military Affairs, where it was approved and placed on the House calendar. Despite the association's lobbying efforts, however, the bill was never brought to the floor because the Speaker and the Rules Committee chairman never called it up. The association's officers made several trips to Washington over the next months to meet with key legislators, including Speaker of the House Thomas B. Reed, who proved to be the legislation's main impediment. Reed wielded immense power, and his fiscal conservatism blocked all efforts to bring the expensive park bill to the floor. ${ }^{32}$

31. William T. Rigby, Report, 12/7/1899, folder 158, box 7, Administrative series, Vicksburg National Military Park (hereafter cited as VNMP); "Veterans are Back," undated newspaper clipping, ibid.; H. C. Landru, "The Vicksburg National Military Park - Its Origin, Growth, and Future Development," 1936, folder 49, box 2, Edwin C. Bearss series, VNMP; James R. McConaghie and Daniel J. Keeffe, "A History of Vicksburg National Military Park," 1954, ibid.; W. T. Rigby, "History and Views of The Vicksburg National Military Park," Vicksburg Monday Morning Democrat, 9/6/1909, in folder 128, box 6, Administrative series, VNMP; "The Vicksburg National Military Park Association," folder 158, box 7, Administrative series, VNMP; Vicksburg Evening Post, 11/30/ 1908.

32. "Charter of Incorporation of the Vicksburg National Military Park Association," folder 158, box 7, Administrative series, VNMP; Rigby, Report; McCon- 
Henderson, however, was working behind the scenes to aid the Vicksburg project, although he did not support Vicksburg as vigorously as he had Shiloh. It was not nearly as dear to his heart. He had not fought there, as he had at Shiloh, where his brother also lay buried. Still, he thought that the Army of the Tennessee's operation sites needed to be preserved, so he worked on Speaker Reed to get the bill to the floor. In fact, some thought that Henderson represented the only chance to get the Vicksburg bill passed. House Committee on Military Affairs chairman J. A. T. Hull (R-IA) commented that "Henderson will have to get us a day if we ever get it up." 33

Henderson continued to work behind the scenes to get the Vicksburg bill to the House floor. In November 1896 he wrote to park supporter J. F. Merry: “Depend upon it I will leave nothing undone to help in the Park bill. We have got to take Reed by the throat at this session." Henderson was disappointed in the effect, however, writing Rigby a month later: "I do not feel very hopeful. I have been pushing the Speaker, but much work is needed in that quarter." Henderson worked to set up an interview for Rigby and Merry with the Speaker, hoping that would sway Reed. 34

Yet Reed continued to refuse to budge on the Vicksburg bill, so it died, only to be brought forward again and again in the following years. The repeated lack of success led some veterans to lose confidence in Henderson. John S. Kountz, who would

aghie and Keeffe, "History of Vicksburg National Military Park," 15; Report of the Proceedings of the Society of the Army of the Tennessee at the Thirty-First Meeting held at Chicago, Ills., October 10-11, 1899 (Cincinnati, 1900), 31:41. For more on the association's proceedings, see the Vicksburg National Military Park Association's minutes dated 11/22-23/1895, 1/10/1896, 12/16/1896, 12/28/ $1898,12 / 7 / 1899$, and 11/28/1900, in folder 158, box 7, Administrative series, VNMP; Report of the Proceedings of the Society of the Army of the Tennessee at the Twenty-Eighth Meeting held at St. Louis, Mo., November 18-19, 1896 (Cincinnati, 1897), 28:55; Proceedings of the Society of the Army of the Tennessee, 1900, 31:44; Vicksburg Evening Post, 11/30/1908; J. A. T. Hull to J. W. Rigby, 12/14/1896, box 2, William T. Rigby Papers, Special Collections, University of Iowa Libraries, Iowa City. The city of Vicksburg gave $\$ 500$ to pay for the officers' travel to Washington.

33. J. A. T. Hull to William T. Rigby, 2/18/1896, folder 3, box 2, Rigby Papers. 34. Henderson to J. F. Merry, 11/6/1896; Henderson to W. T. Rigby, 12/14/ 1896; and Henderson to W. T. Rigby, 12/28/1896, all in box 2, Rigby Papers. 
later become the Vicksburg historian, wrote in 1898, "Our bill is so just and the influence behind it so strong that it is hard to understand why the Speaker will not consent to the fixing of a date for its consideration. . . . General Henderson ought to be able, with his great influence in the House, to have the bill taken up." All the while, Henderson continued to work on Reed, who finally gave in as he prepared to leave the chamber after his resignation in 1899. 35

When the Vicksburg bill finally came to the floors of the House and Senate, the legislation moved quickly. The House passed the bill on February 6, 1899, and the Senate passed it four days later. President William McKinley signed the legislation on February 21, 1899. The speed of the entire process made it evident that Reed had been the only impediment. ${ }^{36}$

Just as he had been after Shiloh's establishment, Henderson was inundated with requests for jobs even before the Vicksburg legislation passed. He responded to one correspondent, "For Heaven's sake don't stir up the question of offices until we get the bill through Congress and signed by the President. Already I am flooded with all sorts of applications for offices. Let us get legislation and take care of the offices afterwards. I do not write in anger but in great earnestness." Once the bill passed Congress, Henderson turned to office seekers, telling one, "I am feeling very happy over the result of our park bill." He then helped secure a position for Iowan Rigby on the Vicksburg Commission, an appointment that was in doubt up to that point. ${ }^{37}$

THE BEHIND-THE-SCENES POLITICS that brought the Vicksburg bill to the floor had an even greater potential impact on future battlefield preservation. Reed had allowed the bill to pass as he was leaving the House and leaving the Speaker's chair open. Whoever filled that position would have a direct impact on how many battlefields, if any, would be preserved in the future. Veterans and preservationists were undoubtedly excited

35. John S. Kountz to W. T. Rigby, 2/14/1898, box 3, Rigby Papers.

36. 55th Cong., 3rd sess., Congressional Record 32 (1899), 2:1518, 1529, 1640, 1678, 1760; Rigby, Report; Vicksburg Evening Post, 2/10/1899, in folder 145, box 6, Administrative series, VNMP; Annual Report of the Secretary of War-1899, 341.

37. Henderson to W. O. Mitchell, 2/9/1899 and 2/14/1899, box 3, Rigby Papers. 


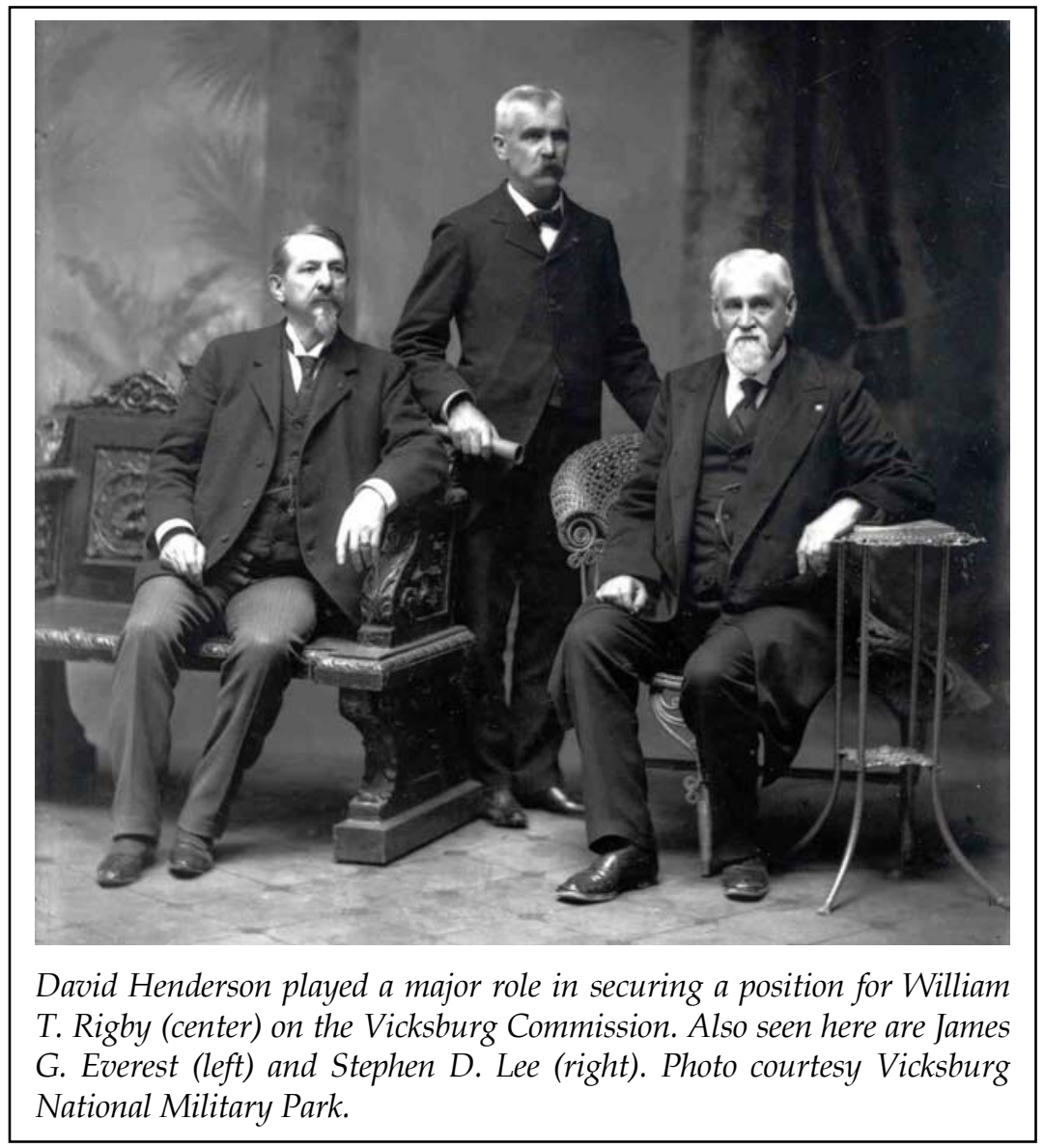

when news of the antipreservationist Reed's retirement became known. They were probably even more elated when news of his successor became public. None other than battlefield preservationist David Henderson was elected Speaker of the House. Surely, there would be no more problems in getting park bills to the floor. Battlefield preservationists could reasonably hope that a time of expansion had arrived with the new leader of the House of Representatives.

Speaker Reed had become increasingly unpopular with members of the House due not only to his domineering manner, but more so because of his anti-imperialist stance in an expansionminded nation. He resigned his seat and his Speaker's position 
to reenter law practice in New York. Ultimately, political wrangling and cloak-room conferences won enough votes for Henderson to defeat rivals such as later Speaker Joseph G. Cannon of Illinois and fellow Iowa representative Albert J. Hopkins. By June 1899, Henderson had the position assured, and he formally took the Speaker's office on December 4, 1899, as the 56th Congress began. One onlooker described him then as "an impressive figure at the Speaker's desk." Henderson revealed his own great sense of duty when he first took the Speaker's stand: "The voice of this House has called me to grave responsibilities. For that call I am most profoundly grateful, and I am keenly sensible of the weight of the responsibilities that attach to this great office." During the next several years, Speaker Henderson firmly ruled the way Reed had, although with more congeniality and tact. One observer remarked, "The verdict of all who served under Speaker Henderson is that, while he walked in the paths made famous by his predecessor, he made these paths easier of access and rendered the task of following his leadership pleasanter and the way smoother." 38

As Speaker, Henderson had national and global affairs to consider rather than primarily the interests of his congressional district and the comparatively smaller matter of battlefield preservation. A major issue during Henderson's tenure as Speaker of the House was the tariff issue, which caused him problems because he differed from the prevailing opinion in Iowa. Another difficulty was expansion, which the anti-imperialist Henderson did not support; the futures of Hawaii, the Philippines, and Puerto Rico were major points of contention in Congress at that time. ${ }^{39}$

Even as he dealt with the major political issues of the day, Speaker Henderson remained involved in the parks he had helped establish. He felt a special bond with the commissions, helping to defeat a bill in 1902 that would have consolidated the

38. "A Few Incidents of the Life of Speaker Reed's Successor"; 56th Cong., 1st sess., Congressional Record 33 (1900), 1:5; Hoing, "David B. Henderson," 5-12; Henderson to William Larrabee, 12/1/1900, William Larrabee Collection Archives, Montauk; Julian W. Richards, "The Passing of Speaker Henderson," undated, file 32, Albert Baird Cummins Papers, SHSI, Des Moines.

39. Hoing, “David B. Henderson,” 13-20. 


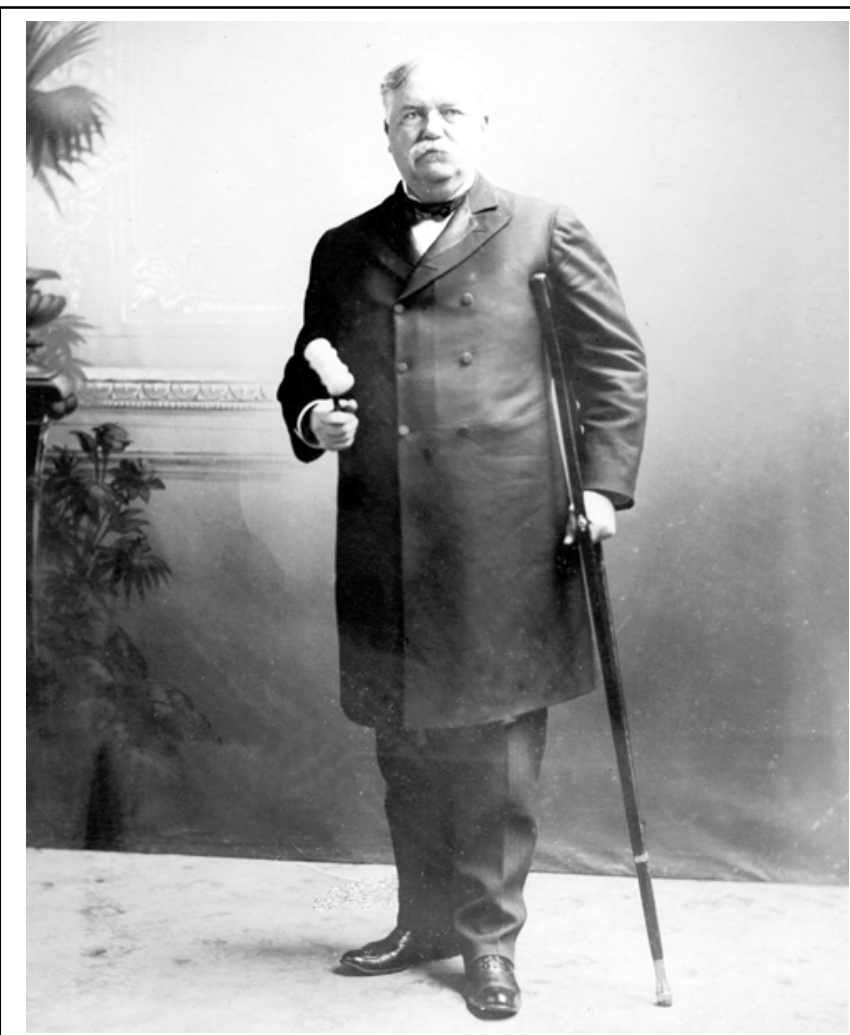

David B. Henderson here poses as Speaker of the U.S. House of Representatives with his gavel in one hand and a crutch in the other, a necessity due to the Civil War injury that resulted in the amputation of his foot and, eventually, much of his leg. Photo from State Historical Society of Iowa, Iowa City.

various battlefield commissions into one, thereby putting several of the old veterans out of work. Old Shiloh friends Cornelius Cadle and David Reed corresponded on the matter, but were not worried because, Cadle reported to Reed, "'Our friend' said he would simply put a 'spike' in this." As Speaker, Henderson was able, as Thomas B. Reed had been, to kill a bill by simply not bringing it to the floor. The 1902 legislation thus died. 40

40. Cornelius Cadle to D. W. Reed, 3/24/1902, folder 628, box 38, series 1 , SNMP; Henderson to George D. Meiklejohn, 3/10/1898, folder 173, box 14, series 1 , SNMP. 
Henderson also became involved in specific park matters. When the Vicksburg Commission became embroiled in a spat with the secretary of war, Henderson sent a letter to the secretary asking, "Is it not possible to get Harmony in regard to the Vicksburgh park between your Department and Commission so that work may be commenced?" Henderson then betrayed his own personal stake in the matter by reminding the secretary, "We are losing important time. Iowa has made large appropriations to build monuments [at Vicksburg] for that state, but . . . it is impossible to go ahead." But Henderson's first love was always Shiloh, of which he wrote affectionately, "As the Shiloh National Park was my child I always feel an interest in whatever pertains to the development of the work." 41

Although Henderson solidly backed the parks that had already been established, the future of battlefield preservation was another issue during his tenure as Speaker. The battlefield preservation of the 1890s would not continue, at least not during the lifetime of most Civil War veterans. Vicksburg would prove to be the last of the great battlefields preserved around the turn of the century, with the next wave not coming until the mid-1920s and 1930s. Evidently, Henderson and the other preservationists became caught up in the fiscal concern over spending money on battlefields. The Shiloh bill had engendered some opposition, and the Vicksburg bill took years to pass. Other battlefield preservation bills in the late 1890s were never even enacted. ${ }^{42}$ Many surely thought that since Speaker Reed was now out of the way, the Civil War veteran Henderson would open the floodgates to battlefield preservation. In fact, Henderson did not even accomplish as much as his friend Reed had. Vicksburg's bill was passed during Reed's tenure; not a single battlefield was preserved while Henderson governed the House of Representatives.

41. Andrew Hickenlooper to Henderson, 5/10/1902, folder 1, box 1, Administrative series, VNMP; John S. Kountz to William T. Rigby, 3/13/1902, folder 34, box 2, William T. Rigby series, VNMP; Henderson to Elihu Root, 5/20/1902, and John P. Nicholson to Secretary of War, 5/15/1902, both in box 1, E 715, RG 92, National Archives; Henderson to George D. Meiklejohn, 3/10/1898, folder 173 , box 14 , series 1 , SNMP.

42. Lee, The Origin and Evolution of the National Military Park Idea, 46-52. 
Although Henderson had few chances to bring up battlefield preservation bills due to a lack of action from the Committee on Military Affairs, he did not even act on the ones that did come out of committee. In the two sessions of the 56th Congress (December 1899-March 1901), a total of ten Civil War park bills (Atlanta, Franklin, Fredericksburg, Bull Run, Petersburg, Perryville, Stones River, Fort Ridgely, Wilson Creek, and Fort Stevens) were submitted for passage, not to mention several bills concerning Revolutionary War battlefields. Of the ten Civil War sites, only three (Stones River, Fredericksburg, and Atlanta) were ever acted on by the committee and reported to the House. The Fredericksburg bill was even passed by the Senate. The problem in the past had been Speaker Reed's refusal to bring the bills to the floor. Curiously, Henderson took the same stance and brought none to a vote, not even the Fredericksburg bill that had cleared the Senate. 43

The 57th Congress (March 1901-March 1903) was even less productive. A total of 11 Civil War park bills were offered (Atlanta, Appomattox, Fredericksburg, Bull Run, Petersburg, Perryville, Stones River, Fort Stevens, Wilson Creek, Franklin, and Ball's Bluff). Again, the Senate passed the Fredericksburg bill. Yet again, however, Henderson did not bring it to the floor. But this time Fredericksburg was the only bill reported favorably. Although most battlefield bills were never dealt with at all, the committee actually took the extra step to report unfavorably on the Appomattox bill. Congress, it seemed, was becoming less and less willing to even talk about battlefield preservation. ${ }^{44}$

It seems curious that Henderson did not call up these bills, and he never explained why. We know that many representatives and senators were becoming alarmed by the cost of such parks and that a backlash was developing against them. We also know - from his interview with veteran John Merry when he said, "This simply can't be done" - that Henderson himself

43. 56th Cong., 1st sess., Congressional Record 33 (1900), 1:55, 221, 579, 594, 637; ibid., 2:1218, 1372, 1425, 1663, 1760; ibid., 3:2866-67, 2913, 2956; ibid., 4:3108; ibid., 6:4961-62, 5104; 56th Cong., 2nd sess., Congressional Record 34 (1902), 4:3265.

44. 57th Cong., 1st sess., Congressional Record 35 (1902), 1:52, 54-56, 95-96, 130, 183, 186, 230, 686; ibid., 2:1109-10, 1198, 1203, 1318; ibid., 3:2470, 2714; ibid., 5:4854; 57th Cong., 2nd sess., Congressional Record 36 (1903), 1:984; ibid., 3:2300. 
was beginning to have his own doubts, not about the need to preserve battlefields, but about the chances of doing so successfully. With fiscal conservatism growing in Congress, perhaps Henderson did not want to fight a battle he did not think he could win. ${ }^{45}$

We also know that, with so many park bills being offered, there was a movement to restructure the commission system that had been put in place in the 1890s. With three salaried commissioners per park, there was little chance that Congress would fund such expenses for all these new sites. Thus, the effort to create one national commission that began in 1902, which Henderson quelled, resurfaced in 1904 and again in 1906 and no doubt affected congressional minds. Perhaps also, in Henderson's mind, if more parks were established, the call for a centralized commission would gain more support, thus putting his friends on the Shiloh and Vicksburg commissions out of their jobs. ${ }^{46}$

On top of those fiscal issues, other events were taking precedence. The Progressive Era as well as the Imperialistic Era, coming after the Spanish-American War, drew congressional attention away from battlefield preservation. These new issues also required funding that in the past might have been used to preserve battlefields. In the War Department itself, Secretary of War Elihu Root was taking the department through a major reconfiguration that aimed at economic efficiency as well as more efficient use of human resources. There was little money or interest for battlefields in such changing times. ${ }^{47}$

There is yet another possible explanation for why Henderson did not forcefully lobby for other battlefields after his major push for Shiloh and Vicksburg. Henderson was a veteran of the Army of the Tennessee, which of course had fought at both places. That army had not fought at Stones River, Appomattox,

45. Vicksburg Evening Post, 11/30/1908; Smith, This Great Battlefield of Shiloh, 26-27.

46. 57th Cong., 1st sess., House Reports, Report No. 2043, 5; 59th Cong., 1st sess., House Reports, Report No. 4431, 1-5, 16; Annual Report of the Secretary of War1904, 39; ibid., 1905, 39; William Gardner Bell, Secretaries of War and Secretaries of the Army: Portraits and Biographical Sketches (Washington, DC, 1982), 100, 102.

47. Nell Irvin Painter, Standing at Armageddon: The United States, 1877-1919 (New York, 1987); Vincent P. DeSantis, The Shaping of Modern America, 18771920 (Wheeling, WV, 1973); Bell, Secretaries of War, 100. 
or Fredericksburg, and thus Henderson was not as enthusiastic about preserving those battlefields. There is ample evidence of army pride being a factor in who supported what battlefields in the 1890s, and Henderson may well have shared that bias. 48

Consequently, although battlefield supporters were justified in applauding Henderson's election as Speaker, his tenure did not produce the desired results. And he served only two short terms in that office before resigning and retiring to Iowa. The best chance to take a giant leap forward in battlefield preservation, coming after the important advances of the 1890s, did not yield positive results. With Henderson's resignation, the speakership went to a nonveteran (Joseph G. Cannon of Illinois) who was even more fiscally conservative than Henderson and Reed. Congress did not establish another single Civil War battlefield until the mid-1920s. The chance had passed; the Golden Age of battlefield preservation came to an end. ${ }^{49}$

HENDERSON lived for only a few years thereafter. He moved back to his home in Dubuque, Iowa, but ill health took its toll. He and his family moved for a time to southern California for his health, but that proved of no help. He died on February 26, 1906, just three years after leaving the House. Iowa mourned his death, and monuments and memorials soon appeared all over the state and elsewhere. A monument to him had already gone up in Clermont, Iowa, the town nearest his boyhood home, and the library at Upper Iowa University had taken his name even before his death. A liberty ship in World War II was named the S.S. Henderson. Perhaps the most important memorial to Henderson, however, was the national military park at Shiloh. ${ }^{50}$

48. Smith, This Great Battlefield of Shiloh, 23; 53rd Cong., 3rd sess., Congressional Record 27 (1895), 1:19.

49. L. White Busbey, Uncle Joe Cannon: The Story of a Pioneer American (New York, 1927); Blair Bolles, Tyrant from Illinois: Uncle Joe Cannon's Experiment with Personal Power (New York, 1951); William Rea Gwinn, Uncle Joe Cannon, Archfoe of Insurgency: A History of the Rise and Fall of Cannonism (New York, 1957). Congress did appropriate some money for Revolutionary War parks and accepted a donation of land at Kennesaw Mountain, but no new Civil War parks were created until the mid-1920s.

50. “Notable Deaths," Annals of Iowa 7 (1906), 394-95; Des Moines Register, 3/6/ 1906; Dubuque Telegraph and Herald, 3/1/1906; Dubuque Daily Times, 2/27/1906; 


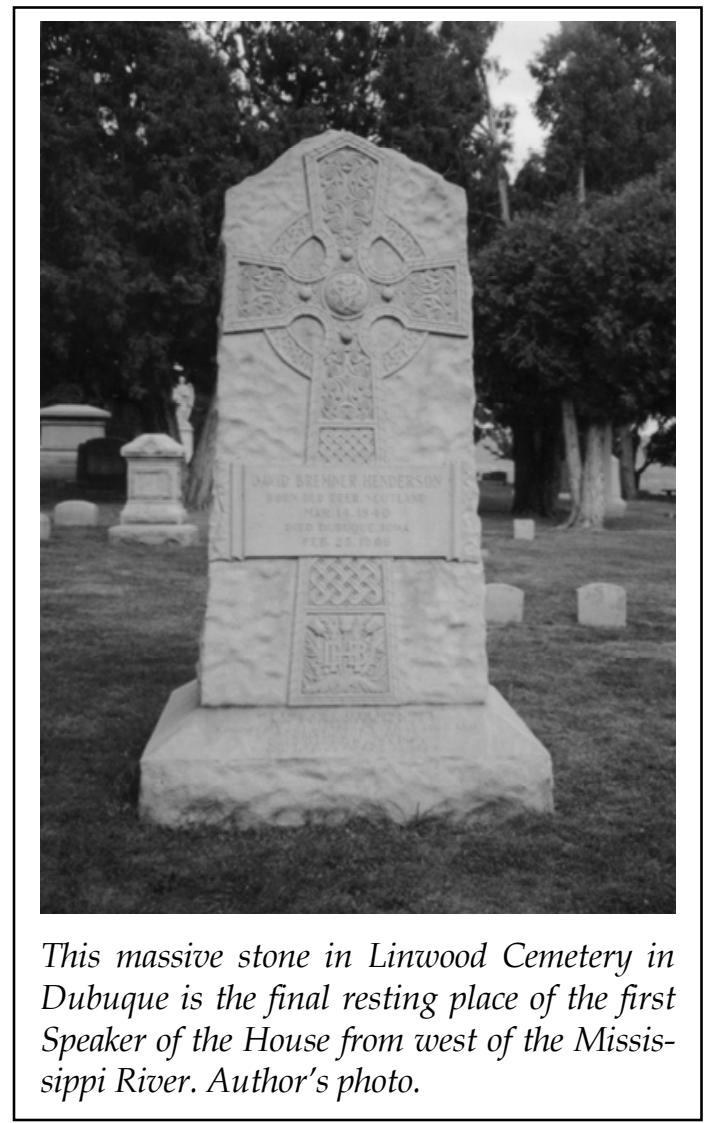

Henderson as a battlefield preservationist can be viewed as a case study of the entire generation of Civil War veterans. His major support for only the Army of the Tennessee's battlefields illustrates the grassroots mentality and disjointed nature of the phenomenon, and the lack of a centralized source of support for the effort. And just as Henderson's early support for establishing the parks began to wane in the 1890s as more and more parks came about and as the price tag grew, so too did the Civil War veteran generation's lobbying efforts decline. By the first years of the twentieth century, Civil War veterans did not seem quite

Hal Babbitt to William Richman, 9/24/1943, Henderson Papers, University of Iowa; "The Henderson Mystery," file 124, Cummins Papers; Hoing, "David B. Henderson," 22-27. 


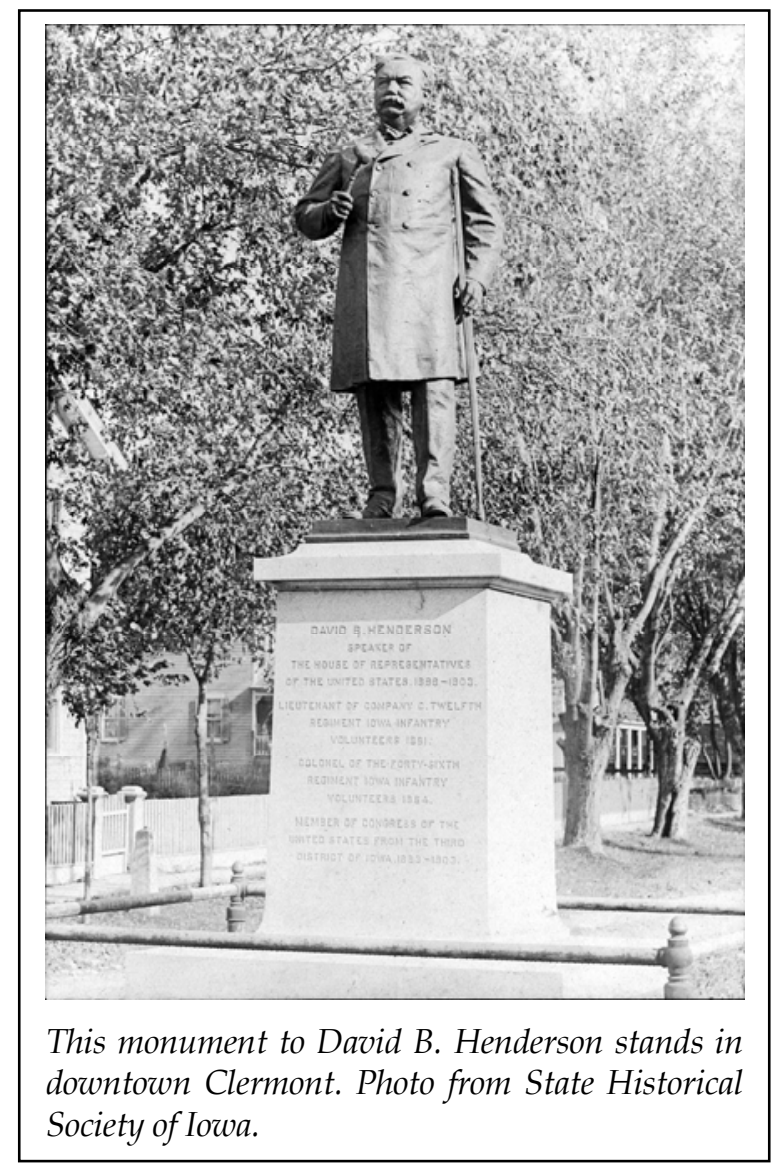

as convinced of the need to establish new battlefields. With Henderson's resignation, a new nonveteran Speaker and a whole new generation of nonveterans took the reigns of government, culture, and society and confronted new issues. Meanwhile, Henderson and the remainder of his generation of veterans slowly and quietly slipped away into the past.

For a brief time in the early 1890s, however, the generation of Civil War veterans had made a concerted effort to preserve the battlefields that represented the memories of their actions back in the prime of their lives. As Henderson prepared to leave the House, he spoke of what he and his generation of veterans had done during the Civil War. His final congressional speech 
to the House reminded that body that he "believed that there was no future moment when disintegration could come to this Republic. And when I saw the young men from every state in the Union touching elbow and rushing into the ranks of war, there was absolute confirmation of that belief. I have no fears for the future of my country." As part of that same remembrance, veterans had preserved some of their battlefields. Even today, 100 years removed from the battles over preservation and nearly 150 years removed from the actual battles themselves, visitors can still walk those quiet fields of conflict and ponder the generation that fought there and then preserved the sites. And so it should be. After all, the battlefields are a testament to those very veterans. ${ }^{51}$

51. 57th Cong., 2nd sess., Congressional Record 36 (1903), 3:3078. 